\title{
A VOZ COMO OBJETO DE UMA ANTROPOLOGIA DA ENUNCIAÇÃO
}

\author{
VOICE AS AN OBJECT OF AN ANTHROPOLOGY OF ENUNCIATION
}

\author{
Valdir do Nascimento Flores | Lattes | valdirnf@yahoo.com.br \\ Universidade Federal do Rio Grande do Sul | CNPq
}

Resumo: Este texto esboça uma abordagem da voz nos estudos da linguagem, em especial, no interior de uma antropologia da linguagem. $O$ trabalho define a enunciação como uma função que caracteriza fundamentalmente o homem na sua condição de homo loquens. Com vistas ao estudo dessa função, é apresentada, em seus aspectos gerais, a ideia de uma antropologia da enunciação, que estuda o saber sobre o homem que advém de sua enunciação. Defende-se, em suma, uma perspectiva teórica que trata dos efeitos da presença da língua no homem. Finalmente, ilustra-se o proposto com uma análise de comentários feitos acerca da voz de cantores brasileiros.

Palavras-chave: Antropologia da enunciação; Voz; Enunciação; Falante.

Abstract: This text outlines an approach to the voice in language studies, especially within an anthropology of language. The study defines enunciation as a function that fundamentally characterizes men in their condition of homo loquens. Aiming to study this function, the idea of an anthropology of enunciation is presented in its general aspects. Such anthropology studies the knowledge about men that comes from their enunciation. Therefore, we defend a theoretical perspective that deals with the effects of the presence of language in men. Finally, we illustrate the proposal with an analysis of comments made about the voice of Brazilian singers.

Keywords: Anthropology of enunciation; Voice; Enunciation; Speaker.

\section{Introdução}

O objetivo geral deste artigo - de certa forma, explícito em seu título - é esboçar uma proposta de entendimento da voz no escopo de uma antropologia da enunciação. Assim formulado, tal objetivo pode, dada a aparente clareza que o caracteriza, encobrir duas necessidades de explicitação conceitual: a noção de "voz" ${ }^{1}$ mobilizada e o enten-

\footnotetext{
${ }^{1}$ Utiliza-se o destaque das aspas na palavra, na Introdução e no decorrer do texto, sempre que se tratar de menção ao termo e não de uso da palavra.
} 
dimento do que vem a ser uma "antropologia da enunciação". Nenhum desses termos é evidente no campo dos estudos da linguagem, merecendo, portanto, maior atenção.

Desse ponto de vista, então, poder-se-ia dizer que há um objetivo anterior ao apresentado acima, cujo duplo propósito seria, de um lado, explicitar os termos pelos quais se pode conceber a "voz" como um objeto passível de abordagem no âmbito dos estudos da linguagem e, de outro lado, evidenciar as linhas fundamentais de uma visada sobre a linguagem, concebida como uma antropologia da enunciação, que comporta a "voz" como objeto de estudo. Em vista disso, este texto se organiza em três partes.

A primeira (cf. item 1) busca definir o sentido de "voz" mobilizado neste estudo. Faz-se isso a partir da análise histórico-crítica da maneira como a "voz" comparece nos estudos da linguagem, em geral, e na linguística, em particular. Conclui-se esse item formulando algumas razões que impuseram uma espécie de "mutismo" da voz nos estudos da linguagem. Ao finalizar a primeira parte, ainda se concebem duas possibilidades - antagônicas metodologicamente - de abordagem da voz: vinculando-a à língua, entendida como factum grammaticae (MILNER, 1995), ou vinculando-a ao falante, entendido como homo loquens, em que a propriedade loquens define uma função que caracteriza fundamentalmente o homem. ${ }^{2}$

A segunda parte (cf. item 2 ) embasa, em linhas gerais, o que se entende pela expressão "antropologia da enunciação", perspectiva que coloca o falante no centro dos estudos da linguagem e que vê na capacidade loquens do homem a fonte de um saber de natureza linguística. A antropologia da enunciação, nesses termos, é apresentada como o estudo do saber do homem que advém da sua capacidade de enunciar. Nessa parte, também se fundamentam os princípios metodológicos de uma tomada antropológica da enunciação, considerando, em especial, a proposição do “contorno de sentido", visível na função metalinguística natural de usar a língua para comentar a língua, como uma categoria de análise da antropologia da enunciação.

Finalmente, na terceira parte (cf. item 3), já de posse das considerações advindas dos itens anteriores, busca-se apresentar a voz no escopo teórico-metodológico esboçado. Ilustra-se o proposto com uma análise de comentários feitos acerca da voz de cantores e cantoras brasileiros.

\footnotetext{
2 Por recomendação dos avaliadores "ad hoc" do artigo, destaca-se que o uso do significante "homem", na construção teórica aqui buscada - de inspiração benvenistiana - circunscreve-se à ideia de "humano". Não se ignora, no entanto, que o mesmo significante, quando usado em outros contextos, pode implicar discursos sexistas.
} 


\section{A voz humana, esta desconhecida}

A ideia principal deste item está contida em seu título: a voz humana é desconhecida tanto dos estudos da linguagem, em geral, quanto dos estudos da linguística, em particular.

Inicialmente, cabe observar que a expressão "voz humana” - que não por acaso dá nome à célebre peça de Jean Cocteau (La voix humane), cuja força poética resulta da profundidade dos sentimentos, demasiado humanos, da personagem - não tem sentido óbvio, sem ambiguidade. Uma rápida vista de olhos no campo dos estudos gerais sobre a linguagem permite ver que à aparente evidência da expressão "voz humana" é possível contrapor algumas considerações que, de um lado, problematizam sua configuração fenomenológica e, de outro lado, colocam em xeque sua real abordagem pelos estudos da linguagem (filosóficos, linguísticos etc.). Observem-se alguns exemplos.

Herman Parret, semioticista e filósofo da linguagem, propõe uma discussão nos seguintes termos: "há sons, ruídos produzidos pelo ser humano, que não pressuponham a voz, que sejam, em certo sentido, anteriores à voz, como o balbucio das crianças e o riso?” Ao que responde: “Tudo dependerá evidentemente da definição de voz que se precisará construir, na sua relação com a sonoridade e com o ruído”. Acrescenta, ainda, que a palavra "voz" pode ser usada apenas metaforicamente, quando aplicada a outros seres (com vida ou não) que não o homem (animais ou máquinas). Isso, no entanto, não é suficiente para “isolar, entre os 'ruídos do mundo', uma classe específica de ruídos ou de sons gerados pela voz humana” (PARRET, 2002, p. 23, itálicos no original, tradução minha).

Grosso modo, o que Parret parece questionar é a existência de um critério seguro que permita isolar ruídos, em geral, de sons produzidos pela voz, em particular. Com base em Aristóteles, ele conclui: "a voz humana, ao contrário do ruído e da voz animal, é eufônica e sinfônica” (PARRET, 2002, p. 26, tradução minha), quer dizer, ela é semantizada e estetizada.

Não muito longe do que diz o semioticista, mas indo em outra direção, o filósofo italiano Giorgio Agamben pergunta:

Existe uma voz humana, uma voz que seja voz do homem como o fretenir é a voz da cigarra ou o zurro é a voz do jumento? E, caso exista, é esta voz linguagem? Qual a relação entre voz e linguagem, entre phoné e logos? E se algo como a voz humana não existe, em que sentido o homem pode ainda ser definido como o vivente que possui linguagem? (AGAMBEN, 2008, p. 10, itálicos no original). 
Distanciando-se de uma visão aristotélica, que articula a voz em termos da relação entre phoné e logos, Agamben supõe um hiato entre voz e linguagem que, no constructo teórico do filósofo, pode abrir espaço para uma ética, na justa medida em que é "um espaço vazio" entre a potência do dizer e o ato.

Também o medievalista Paul Zumthor em resposta à pergunta de André Beaudet, que indagava "como se explica que nós ainda não tenhamos uma ciência da voz?" (ZUMTHOR, 2005, p. 62), assim se manifesta:

A voz se destaca destas evidências por assim dizer tão óbvias, que a reflexão científica só alcança alguns de seus aspectos. Uma ciência da voz deveria abarcar tanto uma fonética quanto uma fonologia, chegar até uma psicologia da profundidade, uma antropologia e uma história. (ZUMTHOR, 2005, p. 62).

E conclui mais adiante: "a língua é mediatizada, levada pela voz. Mas a voz ultrapassa a língua; ela é mais ampla do que ela, mais rica [...] a voz, utilizando a linguagem para dizer alguma coisa, se diz a si própria, se coloca como presença” (ZUMTHOR, 2005, p. $63)$.

Finalmente, Corrado Bologna, talvez a primeira e mais reiterada personalidade dos estudos sobre voz, sentencia:

A sua natureza é essencialmente física, corpórea; está relacionada com a vida e com a morte, com a respiração e com o sono; emana dos mesmos órgãos que presidem à alimentação e à sobrevivência. Antes mesmo de ser o suporte e o canal de transmissão das palavras através da linguagem, a voz é um imperioso grito de presença. (BOLOGNA, 1987, p. 58).

O que essas ínfimas passagens de trabalhos tão densos ilustram? Simplesmente que o tema da "voz" está longe de ser considerado algo pacífico entre aqueles que problematizam a existência humana; daí o pouco poder autoexplicativo da expressão "voz humana" e sua quase nenhuma presença no campo dos estudos da linguagem.

A voz, de fato, tem tantas faces, tantos aspectos, tantas possibilidades de ser escutada que pode, facilmente, interessar a muitos campos do conhecimento, ou a nenhum. No entanto, e isso é inegável, a voz não prescinde da linguagem, embora não equivalha pari passu a ela. E, sendo a linguística uma autoridade em matéria de linguagem, não é fácil não ceder à tentação de ver a voz no escopo da linguística. Mas não de qualquer linguística: de uma linguística que inclua o homo loquens em seu horizonte de possibilidades. 


\subsection{Os termos do mutismo da voz no campo da linguística}

A filósofa Adriana Cavarero, em um livro de rara beleza, Vozes plurais - Filosofia da expressão vocal, parece encontrar a origem tanto da natureza da problematização, na atualidade, quanto da ausência da voz nos estudos da filosofia (e, também, da linguística). Segundo ela, o logos perdeu a voz. Quer dizer, desde a sua origem - e Cavarero está pensando especialmente na filosofia platônica -, a "filosofia tapa os ouvidos" e promove uma desvocalização do logos. O logos, a razão, o discurso, a linguagem, enfim, dizem respeito, na tradição do pensamento filosófico, à conexão de palavras. É nesse plano da conexão, que "liga" de acordo com determinadas regras, que está centrada a atenção da filosofia: "Centrada, inclusive com prejuízo - mas talvez fosse melhor dizer: sobretudo com prejuízo - do plano acústico da palavra” (CAVARERO, 2011, p. 50-51).

Cavarero tem razão. A ausência da voz coincide com a (excessiva?) presença do logos, da razão, que abafa a voz. E a que se deve esse "ensurdecimento racional”?

Ora, a filósofa considera que a voz é uma "unicidade que faz de cada um de nós um ser diferente dos demais" (CAVARERO, 2011, p. 17), e que tal unicidade "não é característica do homem em geral, mas de cada ser humano na medida em que vive e respira” (CAVARERO, 2011, p. 18). No entanto, adverte: não se trata de uma relação tautológica entre a própria voz e o próprio ouvido, "mas de um comunicar-se da unicidade que é, ao mesmo tempo, uma relação com outra unicidade” (CAVARERO, 2011, p. 20, itálico no original), isto é, a voz implica a escuta. Assim, "no registro da voz, ecoa a condição humana da unicidade [...] [e] tal condição é essencialmente relacional" (CAVARERO, 2011, p. 22-23). Ao estudo da problemática da unicidade relacional da voz, Cavarero (2011) chama de fenomenologia vocálica da unicidade.

Assim entendida a voz - como um dado indiscutivelmente singular e único - é fácil compreender o ensurdecimento que a filosofia tem em relação a ela:

A singularidade inimitável de cada ser humano, a unicidade encarnada que distingue cada um de qualquer outro, é, para os gostos universalistas da filosofia, um dado supérfluo, se não desconcertante, além de epistemologicamente impróprio. (CAVARERO, 2011, p. 24).

É uma evidência: esse ensurdecimento gera um distanciamento, pois a tradição filosófica e epistemológica determina que, em proveito da abstração generalizada de vocação universalista da ciência, se evite tratar o que é único, singular e irreproduzível, do que a voz é um exemplo. 
Tal análise e suas consequências são estendidas à linguística ${ }^{3}$ pela própria Cavarero, o que merece ser citado na íntegra apesar da extensão:

A despeito de sua aceleração novecentista e de seus complexos desenvolvimentos, pode-se de fato desenterrar o percurso teórico que leva a linguística moderna a herdar do estatuto metafísico uma desatenção programática sobre a unicidade da voz. O que, obviamente, não depõe contra a legitimidade dos estudos linguísticos nem sequer diminui o seu interesse, mas testemunha, de modo exemplar, como os saberes dirigidos aos fenômenos da palavra podem ocupar-se da voz sem preocupar-se com a singularidade de cada voz. Em outros termos, a voz - estudada na perspectiva da linguagem e, ainda mais, numa perspectiva que entende linguagem como sistema - torna-se a esfera geral das articulações sonoras na qual a unicidade do som é, paradoxalmente, aquilo que não soa. A linguagem enquanto código, a sua alma semântica que aspira ao universal, torna imperceptível, na voz, o próprio da voz. A unicidade plural das vozes não passa pelo filtro metodológico do ouvido linguístico. (CAVARERO, 2011, p. 24-25, itálicos no original, negritos meus).

A análise acima pode causar algum espanto junto aos linguistas, que acreditam estudar o que é tangível da voz, em seus tratados de fonética e fonologia.

Porém, Cavarero pode ter alguma razão. Na fonética e na fonologia, realmente, nada há que fale da singularidade da voz, ao menos não nos termos explicitados pela filósofa. No máximo, a linguística abriga, nos limites bastante rígidos de suas metodologias, aspectos implicados na prosódia - em seu viés acústico ou fonológico (SCARPA, 1999) -, na produção da fala - a partir de recursos tecnológicos de análise acústica (MARCHAL; REIS, 2012) -, no tratamento fonético stricto sensu (CAGLIARI, 2009), entre outros. O Dicionário de fonética e fonologia, por exemplo, não reserva nenhuma de suas entradas a um verbete sobre "voz", embora, evidentemente, trate com bastante propriedade todos os aspectos "relevantes para o estudo do português e da fonética e da fonologia em geral" (SILVA, 2011, p. 8).

É bem verdade, entretanto, que, na atualidade, especificamente com relação aos estudos prosódicos, encontra-se alguma preocupação em tratar algo que se aproxime do que Cavarero considera próprio à unicidade da voz. Barbosa (2010, p. 1), por exemplo, diz que "[...] no cenário de pesquisa atual, a prosódia tem seu campo de estudo nos domínios linguístico, paralinguístico e extralinguístico”. Nos três domínios, segundo o autor,

\footnotetext{
${ }^{3}$ Deve-se excetuar o excelente La vive voix: essais de psycho-phonétique, de Ivan Fónagi (1991).
} 
[...] estudam-se as funções prosódicas de demarcação (indicadores de constituintes prosódicos, como sílabas, palavras fonológicas, grupos acentuais, sintagmas entoacionais, entre outros), proeminência (saliência de um constituinte prosódico em relação a outro) e de marcação discursiva (marcadores de turno num diálogo, modalidade da frase, entre outros). (BARBOSA, 2010, p. 1).

Essas funções prosódicas estão ligadas à entoação, ao ritmo, à “[...] imbricação entre restrições biomecânicas ligadas à produção da fala [...] e restrições linguísticas e paralinguísticas ligadas à percepção da fala [...]” (BARBOSA, 2010, p. 1). Para o autor, as funções linguísticas do ritmo, da entoação, da acentuação, do acento lexical e frasal têm lugar nos estudos linguísticos, já os fenômenos “[...] linguageiros e comunicativos [...]” (BARBOSA, 2010, p. 1) - marcadores discursivos, ênfase, atitudes, emoções e os fenômenos ligados a fatores sociais e individuais (como gênero e sexo, classe social, faixa etária, condição de saúde) - têm lugar nos estudos extralinguísticos e paralinguísticos.

Admitida a distinção feita por Barbosa (2010) entre linguístico, extralinguístico e paralinguístico, o que Cavarero (2011) abriga na ideia de uma fenomenologia vocálica da unicidade teria alguma relação com os ditos fenômenos "linguageiros e comunicativos", uma vez que ali seriam abordados "fatores individuais". Porém, Barbosa (2010) insiste sobre o fato de tais fenômenos terem lugar em estudos extralinguísticos e paralinguísticos, o que resguarda uma especificidade ao "linguístico" que vai ao encontro do que Cavarero (2011, p. 25) denomina de "linguagem como sistema". Sendo os aspectos individuais considerados extralinguísticos ou paralinguísticos, a linguística pode eximir-se de abordá-los.

Em outras palavras, os estudos linguísticos, quando olham para a voz, tratam-na no interior de uma concepção de linguística, de ciência, que é refratária aos ditos "fatores individuais". O efeito disso é a exclusão da unicidade da voz do escopo da linguística, apesar da explícita admissão da existência de elementos na voz que não podem ser tratados no mesmo quadro metodológico da fonética e da fonologia. Em suma, o gesto de reconhecimento da vinculação da voz ao falante é exatamente o mesmo que a exclui da linguística.

Há, de certa forma, um aspecto paradoxal na enunciação vocal, singular e individual, com o qual o linguista tem dificuldades de lidar, e é Émile Benveniste quem assinala isso. Em $O$ aparelho formal da enunciação, ele considera que "o [aspecto] mais imediatamente perceptível e o mais direto - embora de um modo geral não seja visto em relação ao fenômeno geral da enunciação - é a realização vocal da língua” (BENVENISTE, 1989a, p. 82). 
Benveniste (1989a, p. 82) afirma que "os sons emitidos e percebidos [...] procedem sempre de atos individuais, que o linguista surpreende sempre que possível em uma produção nativa, no interior da fala”. No entanto - e é aí que se mostra o aspecto paradoxal da enunciação vocal individual -, normalmente, se procura, em linguística, “[...] eliminar ou atenuar os traços individuais da enunciação fônica recorrendo a sujeitos diferentes e multiplicando os registros, de modo a obter uma imagem média de sons, distintos ou ligados" (BENVENISTE, 1989a, p. 82). Ele adverte:

\begin{abstract}
Mas cada um sabe que, para o mesmo sujeito, os mesmos sons não são jamais reproduzidos exatamente, e que a noção de identidade não é senão aproximativa mesmo quando a experiência é repetida em detalhe. Estas diferenças dizem respeito à diversidade das situações nas quais a enunciação é produzida. (BENVENISTE, 1989a, p. 82-83).
\end{abstract}

Ou seja, Benveniste é claro em destacar - e resgatar - a materialidade corporal da enunciação, isto é, o falante, além de assinalar com veemência a paradoxal atitude do linguista.

A voz - entendida como única e singular - remete ao falante, ao homo loquens, ao corpo, que, como se sabe, excede o limite da ciência. As disciplinas linguísticas, na abordagem que dão ao tema, desviam da realidade do falante em favor da abstração seja da língua como sistema, seja do falante como mero enunciador, locutor, emissor etc.

Consequentemente, exclui-se a voz - e, com ela, o falante - do horizonte da linguística. O homem na sua condição de falante, o homo loquens, não opera na análise linguística da linguagem nem mesmo quando é da voz que se busca falar (FLORES, 2017). Evitando tratar da voz, daquilo que há de único nela, ou seja, do falante, a linguística evita rivalizar com uma forma de fazer ciência na qual impera a repetição do mesmo como critério de verificação.

A despeito desse cenário adverso à abordagem da voz no campo da linguística, vale ainda indagar: é possível uma linguística que comporte, em algum sentido, o estudo da voz? Uma resposta afirmativa exigiria que a linguística se reconfigurasse epistemologicamente de forma a comportar a singularidade como um fenômeno passível de ser tomado como objeto de investigação, o que, em termos linguísticos, coincidiria com a realidade do falante. $\mathrm{O}$ olhar do linguista deveria deixar de mirar a abstração das propriedades linguísticas para fixar os olhos no homo loquens. Não mais a língua, mas o falante que fala sob o efeito de ser constituído pela língua. 
Poder-se-ia, então, admitir - ou, ao menos, conjecturar - dois pontos de vista de tratamento da voz no campo da linguística.

O primeiro, compatível com a cientificidade que caracteriza fortemente a área, em que, apesar de se reconhecer as especificidades de uma enunciação vocal singular, trata-a no âmbito generalizante dos "fatores individuais" extralinguísticos. Têm lugar, aqui, as abordagens fonéticas e fonológicas cujo filtro metodológico evita o falante na condição de homo loquens. Mesmo que possam apresentar matizes de técnicas e procedimentos, os estudos oriundos desse ponto de vista têm em comum o olhar para o que Jean-Claude Milner (1995) chama de factum grammaticae:

Se existe uma ciência da linguagem, ela deve atribuir propriedades à linguagem; isso supõe que ela atribui propriedades a cada língua; e isso supõe, por sua vez, que ela atribui propriedades a cada fragmento de uma língua. Mas o que garante que seja simplesmente possível, de maneira geral, atribuir propriedades a dados da língua? A resposta sobre esse ponto é simples: a garantia consiste somente na existência, de fato, do que chamamos gramáticas. Toda e qualquer gramática consiste em atribuir propriedades a um dado de língua. Se as gramáticas existem de fato, então, é preciso concluir que uma tal atribuição é possível. Em outras palavras, a linguística como ciência se apoia sobre o factum grammaticae (MILNER, 1995, p. 54-55, tradução minha).

Do factum grammaticae - que poderia ser entendido tanto como o sistema que os linguistas tentam estabelecer quanto como as descrições propostas para esse sistema está excluído o homo loquens, o que conduz, imediatamente, ao segundo ponto de vista possível acerca da voz. Neste, o olhar é dirigido menos à "gramática" de uma língua e mais ao sujeito falante, ao homo loquens. Desse olhar, aqui nomeado antropologia da enunciação, deve surgir uma perspectiva que coloca em evidência um saber sobre a língua que advém do fato de o homem falar.

A antropologia da enunciação é uma outra linguística, talvez menos científica, que supõe que o fato de a língua ser constitutiva do homem dá-lhe a condição de especial "conhecedor" da língua.

\section{A língua no homem: uma antropologia da enunciação}

O objetivo desta parte é definir, em linhas gerais, a enunciação como uma função que caracteriza o homo loquens e identifica o caráter fundamentalmente verbal da condição humana. A enunciação - em uma inspiração nitidamente benvenistiana - é entendida, aqui, como o ato de dizer algo que coloca em cena um saber sobre a natureza loquens 
do homem. Essa função constitui um objeto antropológico ${ }^{4}$ na justa medida em que dá a conhecer os efeitos da presença da língua no homem. A antropologia da enunciação visa, portanto, esse saber sobre o homem que advém do fato de o homem falar.

Com a formulação a língua no homem, opera-se, conscientemente, uma inversão à expressão o homem na língua, com a qual Émile Benveniste nomeia a quinta parte de seus Problemas de linguística geral. A língua no homem, colocada no centro de uma antropologia da enunciação, evoca como objeto fenômenos - a voz talvez seja um dos mais evidentes, mas há outros (a tradução, a aquisição, a dissolução, a arte verbal etc.) - que dão as condições necessárias e suficientes para que se investigue um saber sobre a língua a partir do sujeito falante.

Nesses termos, a antropologia da enunciação resgata para o seu interior a grande lição de Jakobson (1974, p. 34), para quem “a linguística interessa-se pela linguagem em todos os seus aspectos - pela linguagem em ato, pela linguagem em evolução, pela linguagem em estado nascente, pela linguagem em dissolução”.

Enfim, que consequências há, para uma linguística, pensar a língua no homem?

Em um primeiro momento, é preciso compreender que se trata de uma antropologia no sentido amplo de "conhecimento do homem" e não em algum sentido específico ou aplicado a um domínio qualquer. Além disso, trata-se de uma antropologia da enunciação, quer dizer, do dizer do homem acerca da presença da língua nele. Ou seja, o homem fala do fato de experienciar, em diferentes fenômenos, a presença da língua nele.

Desse ponto de vista, a antropologia da enunciação estuda o fato de o falante tematizar a sua posição de falante ao tratar de fenômenos em que ele está implicado como falante. Assim, dá-se destaque ao retorno reflexivo que o falante produz ao falar sobre como opera a língua nele.

A categoria que dá acesso aos procedimentos analíticos que desvelam a presença da língua no homem é o comentário, entendido como um contorno de sentido, isto é, uma operação natural do falante que visa à explicação e à compreensão das formas e da presença da língua nele. O contorno de sentido é uma espécie de hermenêutica natural, na medida em que o falante fala para atribuir sentido à sua posição de falante em função de um dado

\footnotetext{
${ }^{4}$ A reflexão antropológica visada aqui - de inspiração kantiana (LALANDE, 1996, p. 73) - diz respeito ao homem em geral. Ou também, como lembra Todorov, a respeito da expressão "antropologia geral": "a palavra pode também ser tomada em seu sentido literal de 'conhecimento do homem' para designar o conceito que temos acerca do humano e que estaria subjacente às diversas explorações das ciências humanas assim como aos discursos morais ou políticos, ou, ainda, à filosofia” (TODOROV, 2014, p. 9). O linguista Émile Benveniste também utiliza o termo neste sentido: "vemos todo o conjunto das ciências humanas se desenvolver, formar-se toda uma grande antropologia (no sentido de 'ciência geral do homem')" (BENVENISTE, 1989c, p. 38).
} 
fenômeno linguístico. O contorno de sentido pertence, portanto, à função metalinguística natural e produz uma hermenêutica natural.

De certa maneira, o comentário, o contorno de sentido, é uma narrativa que o falante produz sobre sua história de falante, o que o alça à condição de um etnógrafo da própria língua (FLORES, 2016). Em resumo, o contorno de sentido é um comentário que o falante faz sobre a experiência linguística - dele ou de um outro falante - no contexto de um fenômeno linguístico qualquer. O comentador enfoca o conjunto dos meios expressivos utilizados por ele mesmo ou pelo outro; sobre esse conjunto é produzido um contorno de sentido, ou seja, um saber que o falante articula, uma interpretação sobre um elemento qualquer de um dado fenômeno, ${ }^{5}$ Fazendo uso da natureza metalinguística da linguagem, o falante coloca em prática a capacidade de delimitar mecanismos necessários e suficientes para que a propriedade da linguagem de interpretar a si mesma (BENVENISTE, 1989b, p. 62) se efetive.

Ao linguista interessado no que se está propondo, caberia ver as condições de elaboração de um pensamento sobre a língua cujo parâmetro é o falante. Esse pensamento, sob a aparência de um comentário "leigo", esconde uma sofisticada operação, qual seja: a de cada falante voltar reflexivamente sobre as possibilidades significativas particulares que cada fenômeno de língua opera.

Em outras palavras, o falante, ao falar sobre os efeitos que os diferentes fenômenos de língua têm sobre ele, se historiciza como homo loquens em sua língua. Nesse sentido, uma antropologia da enunciação não estuda dados, mas fenômenos e, em especial, o que o falante diz de sua relação com esses fenômenos.

No entanto, é bom que se advirta, a antropologia da enunciação, ao mirar o que diz o falante sobre fenômenos da língua - a tradução, a aquisição, a dissolução e a voz, entre outros -, não faz teoria deles. Isto é, a antropologia da enunciação, ao estudar o que diz o falante de sua experiência com a diversidade das línguas em uma situação de tradução, por exemplo, não produz uma teoria da tradução, mas uma reflexão sobre o efeito da tradução na experiência de falante. É nesse sentido que se estuda um saber que advém do fato de o homem enunciar; é nesse sentido, também, que se considera que é a língua no homem que determina esse saber.

Ocorre o mesmo com a voz. A antropologia da enunciação, ao tematizar a presença da voz no homem, não produz uma teoria da voz, uma fonética ou uma fonologia novas,

\footnotetext{
${ }^{5}$ Com essa ideia, espera-se deixar claro que o falante pode comentar tanto a sua própria experiência de falante como a de outro qualquer. Nos dois casos, se trata de uma "etnografia" de si, uma vez que o falante explicita sua relação tanto na condição de falante propriamente dito como na condição de quem produz uma escuta.
} 
mas tão-somente uma reflexão sobre o homem como falante, ou melhor, sobre a experiência do homem acerca do fato de que tem voz.

Talvez, enfim, a partir do olhar de uma antropologia da enunciação, a linguística esteja em melhores condições de responder a excelente questão de Claude Hagège (1985, p. 10): "que lugar cabe à linguagem na definição do homem"?

\section{A voz no contexto de uma antropologia da enunciação}

Em 2012, a revista Rolling Stones Brasil, de circulação nacional, especializada em música, publicou, em sua 73a edição, uma lista do que considerou, à época, "as 100 maiores vozes da música brasileira” (AS 100, 2012). Na apresentação da lista, assim se manifesta a revista:

Na edição de aniversário de seis anos da Rolling Stone Brasil, mantemos a tradição de apresentarmos as listas definitivas da música brasileira e mundial. Desta vez, o ranking, elaborado por um time de 60 especialistas, define quais são as 100 maiores vozes da história da nossa música. O que é ter uma voz marcante? Naturalmente, qualidades como potências e afinação são bem-vindas. Mas muitas vozes transmitem emoção e expressividade, mesmo sendo fora do padrão. (AS 100, 2012, grifo meu).

Independentemente da pertinência, ou não, da elaboração de listas como essas - que hierarquizam elementos de naturezas muito distintas e com características tão singulares que inviabilizam qualquer termo de comparação -, o fato é que a revista faz acompanhar a lista uma pergunta, grifada acima, fundamental para os propósitos deste texto. Observar os termos pelos quais a revista encaminha respostas a essa pergunta deve permitir reunir elementos para pensar os aspectos antropológicos da enunciação ligados à voz. ${ }^{6}$

Além disso, a revista publicou, juntamente com a lista, uma série de comentários feita por também cantores (inclusive alguns constantes no dito inventário) acerca das vozes então "classificadas". Tais comentários merecem alguma atenção no âmago de um estudo antropológico da enunciação. ${ }^{7}$ Observe-se, abaixo, a lista de comentários relativos aos "dez primeiros colocados", em ordem crescente:

1) O cantor Seu Jorge a propósito da voz de Tim Maia: “O timbre de Tim Maia era muito particular e muito pessoal. De grande extensão, ia do grave ao agu-

\footnotetext{
${ }^{6}$ Há autores que se dedicam exclusivamente ao estudo da "palavra cantada", tema este que não recobre a noção de "fala". Para maiores esclarecimentos ver: Cagliari (2009, p. 159) e Carmo Jr. (2007 e 2012).

7 Observe-se que, no tratamento do corpus, a seguir, são analisados comentários de terceiros sobre as vozes dos cantores destacados. Isso se coaduna com o que foi dito na nota 4 (acima) quanto à possibilidade de se desenvolver uma reflexão acerca da atividade metalinguística sobre a voz que considere a atenção reflexiva em relação à voz do outro.
} 
do e era marcante, com o sotaque da música brasileira. Você percebe samba, jovem guarda, forró, tudo fundido dentro dessa particularidade de black music" (AS 100, 2012);

2) A cantora Maria Rita sobre a voz de Elis Regina: "Buscava a perfeição no que fazia, não nivelava por baixo, não se contentava com pouco. E ela era, sim, uma musicista, com destaque especial pra sua noção de divisão, onde e como colocar notas curtas, onde sustentar uma nota, sempre pensando na história que a letra contava" (AS 100, 2012);

3) A cantora Rita Lee a propósito da voz de Ney Matogrosso: "[...] é incomparável. Nunca houve entre os cantores brasileiros uma figura tão sedutora, chique e atrevida. Públicos feminino e masculino são hipnotizados por sua voz e presença. Não há quem não fique apaixonado. O timbre da voz é inigualável. Quando se ouve, sabe-se na hora quem é. Isto se chama personalidade e ele a aplica em todos os poros de sua arte. Bobagem falar em momentos mais importantes da vida de um artista do calibre dele, que nunca se repete. Foi inesquecível quando o vi pela primeira vez. Foi uma aparição do outro mundo: um ET elegante vestindo um kabuki mucho louco com uma voz assexuada, cantando uma ciranda portuguesa" (AS 100, 2012);

4) O cantor Max de Castro a propósito da voz de Wilson Simonal: "Simonal inaugurou uma nova escola de canto no Brasil. Ele uniu todas as escolas vocais, desde o cool da bossa nova até a potência vocal, acrescentando uma influência do suingue, na maneira mais criativa de se interpretar uma música. Não somente por saber cantar as notas originais, mas também por criar uma divisão diferente e novas possibilidades de melodias paralelas" (AS 100, 2012);

5) O cantor Caetano Veloso a propósito da voz de Maria Bethânia: "Bethânia surgiu para o público como apenas e exclusivamente uma voz. Foi na Bahia. O diretor de teatro Álvaro Guimarães montou O Boca de Ouro, de Nelson Rodrigues, e o espetáculo abria com um longo blackout em que se ouvia a voz de uma garota desconhecida cantando 'Na Cadência do Samba', de Ataulfo Alves. Ela tinha 17 anos, mas era já essa voz de timbre rico e afeto intenso que nos impressiona até hoje. Ninguém via a figura que sustentava aquela voz nas trevas. Mas o espetáculo começava com uma força ímpar no teatro mundial. Conheço a voz de Bethânia desde dentro: ela foi se desenvolvendo pertinho 
de mim - e tinha os elementos genéticos que estão presentes na minha própria voz, na de meus outros irmãos, na de meus filhos” (AS 100, 2012);

6) O cantor Marcelo Jeneci a propósito da voz de Roberto Carlos: "Sua voz é a voz do amigo que a gente precisa ter durante toda a vida. Esse feito fez dele um dos compositores mais importantes na história da música brasileira” (AS 100, 2012);

7) A cantora Tulipa Ruiz a propósito da voz de Gal Costa: “[...] é uma das mais bonitas que já ouvi. O jeito que ela se apropria das letras, da história, me faz pensar que ela está totalmente à vontade dentro de uma música. Gal se relaciona com o que canta" (AS 100, 2012);

8) O cantor Ney Matogrosso a propósito da voz de Caetano Veloso: “[...] se transformou num cantor maravilhoso quando voltou da Inglaterra, deu um pulo enorme. Até então eu o achava em tudo excelente, menos como cantor. Ele descobriu lá um jeito de cantar que depois evoluiu muito” (AS 100, 2012);

9) O cantor Paulinho da Viola a propósito da voz de Clara Nunes: “[...] era uma cantora que a gente ouvia e sabia imediatamente quem era. Tinha uma voz muito bonita e foi muito importante para o samba e para a música brasileira. Como intérprete, fez parte de uma geração de cantoras que você ouvia e sabia imediatamente quem era, porque elas tinham sua forma de interpretar, deixavam sua identidade na voz" (AS 100, 2012);

10) O cantor Samuel Rosa a propósito da voz de Milton Nascimento: “[...] é um dos principais artistas da música brasileira. Ele sintetiza, na inovadora assinatura musical dele, uma série de habilidades. Tem voz linda e um timbre inconfundível e muito particular. Ao ouvi-lo, não se faz referência direta a algo da nossa música, mesmo havendo mistura riquíssima ali de música mineira, sacra, hispânica e latina, e até dos Beatles e do folk de Dylan” (AS 100, 2012).

Os comentários acima, em que a voz é considerada na constituição da música, encontram eco em um belo texto de Roland Barthes, "A música, a voz, a língua”, no qual ele afirma: "a minha avaliação da música passa pela voz" (BARTHES, 2009b, p. 266). E acrescenta, a propósito da voz em sua relação com a música:

A voz humana é, com efeito, o lugar privilegiado (eidético) da diferença: um lugar que escapa a toda a ciência, pois não há nenhuma ciência (fisiologia, história, estética, psicanálise) que esgote a voz: classifiquem, comentem 
historicamente, sociologicamente, esteticamente, tecnicamente a música, haverá sempre um resto, um suplemento, um lapsus, um não dito que se designa ele próprio: a voz. (BARTHES, 2009b, p. 266, itálico no original, negrito meu).

Tem razão Barthes: a voz humana é refratária à indiferença, portanto, refratária a um discurso completamente conformado a um ideal de cientificidade, porque "não há nenhuma voz humana no mundo que não seja objeto de desejo - ou de repulsa” (BARTHES, 2009b, p. 266, itálico no original).

Os comentários acima, na medida em que constituem um discurso sobre a voz, são um excelente exemplo do que fala Barthes, além de, ao traduzirem a voz pela língua, ser uma ilustração do que foi antes considerado uma hermenêutica natural. É desse ponto de vista que serão tratados aqui.

Como, nesses comentários, a língua traduz a voz? O conjunto dos comentários permite, incialmente, surpreender vários aspectos da voz - interligados entre si - que buscam ser "colocados em palavras".

Há, inicialmente, a apreciação a partir da eleição de elementos técnicos - "timbre" (1); "extensão" (1), "grave” (01); "agudo" (1); "notas curtas" (2), "sustentar uma nota” (2); "timbre da voz" (3); "uma divisão diferente" (4); "timbre” (5); "timbre” (10) -; há, também, a apreciação estética sob a forma de uma avaliação predicativa (cf. BARTHES, 2009a; 2009b) - "era marcante” (1); “é incomparável” (3); “é inigualável” (3); “é a voz do amigo" (6); "é uma das mais bonitas" (7); "tinha uma voz muito bonita" (9); "tem voz linda” (10) -; e há, por último, a constatação da fenomenologia vocálica da unicidade de que fala Cavarero (2011) - "era muito particular e muito pessoal" (1); "quando se ouve, sabe-se na hora quem é" (3); "a gente ouvia e sabia imediatamente quem era" (9); "identidade na voz" (9); "muito particular" (10).

Esse conjunto - traduzido na língua via terminologia técnica, predicativo e reconhecimento da unicidade - constitui uma primeira possibilidade de a língua falar sobre a música; constitui também uma primeira possibilidade de situar o homo loquens.

No entanto, há, também, o que excede essa apreciação e que diz respeito à figura do sujeito falante, do homo loquens. Uma pergunta que cabe, aqui, é: como a língua traduz o saber que advém da enunciação, objeto da antropologia da enunciação? Ou ainda: como a voz, nesses comentários, pode ser vista como objeto de uma antropologia da enunciação?

Em uma primeira interpretação, poder-se-ia pensar que o fato de o conjunto dos comentários dirigir-se sempre a um nome próprio, o cantor ou a cantora "donos da voz", 
evidenciaria uma instância de referência ao falante. Não é essa a proposta que se está defendendo aqui.

O homo loquens, termo que resume a proposta de uma antropologia da enunciação, não é o homo sapiens - o protagonista das histórias sobre a evolução humana -, nem mesmo as representações figurativas que a linguística construiu ao longo de sua abertura à natureza discursiva da linguagem (os locutores, enunciadores, sujeitos etc.). O homo loquens é constituído na linguagem e sua natureza é feita de linguagem. Ele é sujeito por ser falante, um sujeito falante. Assim, antes de ser uma categoria da antropologia da enunciação, ele é a sua condição. Por isso, a enunciação do homo loquens deixa à mostra um saber sobre a sua natureza, sobre os efeitos da presença da língua nele.

E que saber os comentários deixam vir à tona?

Ora, esse saber aparece precisamente na falta de "objetividade" que gira em torno da palavra técnica, falta esta que é preenchida de maneira a evidenciar um saber sobre a língua que é de ordem quase metafísica: o timbre de Tim Maia, além de suas características técnicas, tem "sotaque da música brasileira" (1); a "noção de divisão" de Elis Regina é acompanhada de um "sempre pensando na história que a letra contava" (2); o "timbre da voz" de Ney Matogrosso hipnotiza (3); o timbre da voz de Maria Betânia é "rico" e de "afeto intenso" (5).

Soma-se a isso um outro ponto fundamental: os aspectos interligados entre si tentam falar sobre algo para o que a língua não oferece uma palavra pronta: a voz de Milton Nascimento (10), por exemplo, além de "linda" e de "um timbre inconfundível e muito particular", "não faz referência direta a algo da nossa música”, embora apresente uma "mistura riquíssima”. A voz de Maria Bethânia (5), por sua vez, requer até uma metáfora espacial, pois o comentador afirma conhecê-la "desde dentro".

Não há a palavra certa para nomear a voz. Resta apenas contorná-la de sentido. Esse contorno (FLORES, 2016) permite ao falante falar semanticamente da materialidade da língua, o que explicita um saber, o seu saber, acerca dela. Esse saber cumpre uma função quase etnográfica na economia - no arranjo ou modo de funcionar de diversos elementos de um conjunto maior - do uso da língua. É nesse sentido que se poderia defender que o falante, ao falar da língua - muito especialmente, da materialidade da língua -, é um etnógrafo da própria língua. Essa etnografia se apresenta na interpretação que faz da língua, através dos comentários que a tomam, no caso da voz, via significante.

Enfim, vale lembrar que o que se vê nos comentários é uma tentativa de a língua traduzir a voz através daquilo que se escuta dela. O que pulsa numa voz escapa àquilo que 
geralmente costuma se tomar como sua porção "tangível” (o tom, o volume e as tantas tentativas de adjetivá-la - voz rouca, voz áspera etc.). Porém, os sons emitidos pelo homem, através da voz, são dinâmicos e efêmeros. Logo, falar em voz é falar em efeitos. Em que lugar a voz encontra abrigo? Na escuta do outro.

Assim, o próprio da voz humana é o fato de que ela significa de uma maneira paradoxal: ela é, simultaneamente, o específico de cada um - que, inclusive, não admite reprodução ou cópia -, e o partilhado com o outro. A voz tem essa propriedade de ser única e, ao mesmo tempo, social. Talvez, por isso, seja tão própria para dar voz ao homo loquens na linguística.

\section{Conclusão}

Do que foi dito, uma conclusão se impõe: de um lado, não se pode ignorar que a voz não se conforma à linguística, ao menos não aos moldes de ciência sobre os quais se edifica a linguística moderna; de outro lado, não se pode negar que a voz humana não é algo que se opõe à linguagem.

No entanto, quando se trata da voz, está-se frente ao homo loquens - ao homem falando com outro homem, como diria Benveniste (1995, p. 285) -, ao homem que se apresenta como tal ao falar. E o homem transcende o objeto da linguística. Seria necessário refundar o olhar da linguística sobre a linguagem para, nele, incluir o homem falante e, com este, a sua voz. Seria preciso, portanto, renunciar à mestria que o discurso científico da linguística fornece.

As conclusões esboçadas neste texto, então, não pertencem ao campo da ciência da demonstração, embora não cheguem a ignorá-lo completamente. Em outras palavras, pela natureza da problemática que a voz evoca, nem seria justo vinculá-la integralmente e nem opô-la completamente à ciência linguística.

A expressão homo loquens sintetiza a proposta aqui esboçada e, nesse sentido, pode encontrar abrigo em uma outra linguística, que admite o falante, logo, o homem, no seu interior. Esboça-se aqui, então, uma linguística do falante, neste artigo, também nomeada “antropologia da enunciação”.

\section{Referências}

AGAMBEN, G. Infância e história: destruição da experiência e origem da história. Belo Horizonte: Editora da UFMG, 2008.

AS 100 maiores vozes da música brasileira. Rolling Stone Brasil, São Paulo, n. 73, out. 2012. Disponível em: http://rollingstone.uol.com.br/listas/100-maiores-vozes-da-musicabrasileira/. Acesso em: 15 jan. 2018. 
BARBOSA, P. A. Prosódia: uma entrevista com Plínio A. Barbosa. ReVEL, v. 8, n. 15, 2010. Disponível em: http://www.revel.inf.br/files/entrevistas/revel_15_entrevista_ plinio.pdf. Acesso em: 15 jan. 2018.

BARTHES, R. O grão da voz. In: . O óbvio e o obtuso. Lisboa: Edições 70, 2009a. p. 255-264.

. A música, a voz, a língua. In: . O óbvio e o obtuso. Lisboa: Edições 70, 2009b. p. 265-271.

BENVENISTE, E. O aparelho formal da enunciação. In: . Problemas de linguística geral II. São Paulo: Pontes, 1989a. p. 81-90.

. Semiologia da Língua. In: . Problemas de linguística geral II. São Paulo: Pontes, 1989b. p. 43-67.

. Esta linguagem que faz a história. In: . Problemas de linguística geral II. São Paulo: Pontes, 1989c. p. 29-40.

. Da subjetividade na linguagem. In: . Problemas de linguística geral I. São Paulo: Pontes, 1995. p. 284-293.

BOLOGNA, C. Voz. In: Enciclopédia Einaudi - Volume 11 - Oral/escrito; argumentação. Lisboa: Imprensa Nacional Casa da Moeda, 1987.

CAGLIARI, L. C. Elementos de fonética do português brasileiro. São Paulo: Paulistana, 2009.

CARMO JR. J. R. Melodia \& Prosódia: um modelo para a interface música-fala com base no estudo comparado do aparelho fonador e dos instrumentos musicais reais e virtuais. 2007. Tese de doutorado, FFLCH/USP, São Paulo, 2007.

. Sobre a gramática da palavra cantada. Cadernos de estudos linguísticos, Campinas, v. 54, n. 2, 2012. Disponível em: https://periodicos.sbu.unicamp.br/ojs/index.php/cel/ article/view/8636602/4321. Acesso em: 30 setembro 2018.

CAVARERO, A. Vozes plurais: filosofia da expressão vocal. Belo Horizonte: Editora da UFMG, 2011.

FLORES, V. N. O falante como etnógrafo da própria língua: uma antropologia da enunciação. Letras de Hoje, v. 50, p. 90-95, 2016.

. A voz, "essa cabeça de Medusa”. In: MALISKA, M. E.; SOUZA, P. (Org.). Abordagens da Voz: a partir da Análise do Discurso e da Psicanálise. Campinas: Pontes, 2017.p. 119-133.

FÓNAGY, I. La vive voix: essais de psycho-phonétique. Paris: Payot, 1991.

HAGÈGE, C. L'Homme de paroles. Paris: Librairie Arthème Fayard, 1985.

JAKOBSON, R. Linguística e comunicação. São Paulo: Cultrix, 1974.

LALANDE, A. Vocabulário técnico e crítico da filosofia. São Paulo: Martins Fontes, 1996. 
MARCHAL, A.; REIS, C. Produção da fala. Belo Horizonte: Editora da UFMG, 2012. MILNER, J.-C. Introduction à une science du langage. Édition abrégée. Paris: Éditions du Seuil, 1995.

PARRET, H. La voix et son temps. Bruxelas: De Boeck \& Larcier, 2002.

SILVA, T. C. Dicionário de fonética e fonologia. São Paulo: Editora Contexto, 2011.

SCARPA, E. Apresentação. In: . (Org.). Estudos de prosódia. Campinas: Editora da UNICAMP, 1999. p. 7-15.

TODOROV, T. A vida em comum: ensaio de antropologia geral. São Paulo: Editora Unesp, 2014.

ZUMTHOR, P. Presença da voz. In: . Escritura e nomadismo. São Paulo: Ateliê Editorial, 2005. p. 61-102.

Data de submissão: $21 / 01 / 2018$

Data de aceite: 13/06/2018 